University of Nebraska - Lincoln

DigitalCommons@University of Nebraska - Lincoln

Publications, Agencies and Staff of the U.S.

Department of Commerce

U.S. Department of Commerce

2012

\title{
A multi-beach study of Staphylococcus aureus, MRSA, and enterococci in seawater and beach sand
}

\author{
Kelly D. Goodwin \\ National Oceanic and Atmospheric Administration (NOAA), kelly.goodwin@noaa.gov \\ Melody McNay \\ Southern California Coastal Water Research Project \\ Yiping Cao \\ Southern California Coastal Water Research Project \\ Darcy Ebentier \\ Southern California Coastal Water Research Project \\ Melissa Madison \\ Southern California Coastal Water Research Project \\ See next page for additional authors
}

Follow this and additional works at: https://digitalcommons.unl.edu/usdeptcommercepub

Part of the Environmental Sciences Commons

Goodwin, Kelly D.; McNay, Melody; Cao, Yiping; Ebentier, Darcy; Madison, Melissa; and Griffith, John F., "A multi-beach study of Staphylococcus aureus, MRSA, and enterococci in seawater and beach sand" (2012). Publications, Agencies and Staff of the U.S. Department of Commerce. 340.

https://digitalcommons.unl.edu/usdeptcommercepub/340

This Article is brought to you for free and open access by the U.S. Department of Commerce at DigitalCommons@University of Nebraska - Lincoln. It has been accepted for inclusion in Publications, Agencies and Staff of the U.S. Department of Commerce by an authorized administrator of DigitalCommons@University of Nebraska - Lincoln. 


\section{Authors}

Kelly D. Goodwin, Melody McNay, Yiping Cao, Darcy Ebentier, Melissa Madison, and John F. Griffith 


\title{
A multi-beach study of Staphylococcus aureus, MRSA, and enterococci in seawater and beach sand
}

\author{
Kelly D. Goodwin ${ }^{a, *, 1}$, Melody McNay ${ }^{b, c}$, Yiping Cao ${ }^{b}$, Darcy Ebentier $^{b}$, Melissa Madison $^{b}$, \\ John F. Griffith ${ }^{b}$ \\ ${ }^{a}$ National Oceanic and Atmospheric Administration (NOAA), AOML, 4301 Rickenbacker Cswy, Miami, FL 33149, USA \\ ${ }^{\mathrm{b}}$ Southern California Coastal Water Research Project, Costa Mesa, CA 92626, USA \\ ${ }^{\mathrm{c}}$ Cooperative Institute of Marine and Atmospheric Studies, Rosenstiel School of Marine and Atmospheric Science, University of Miami, \\ Florida 33149, USA
}

\section{A R T I C L E I N F O}

Article history:

Received 26 November 2011

Received in revised form

1 April 2012

Accepted 2 April 2012

Available online $\mathrm{xxx}$

Keywords:

Staphylococcus aureus

MRSA

Recreational water quality

Enterococci

Seawater

Beach sand

\begin{abstract}
A B S T R A C T
Incidences of Staphylococcus aureus and methicillin resistant S. aureus (MRSA) have risen worldwide prompting a need to better understand routes of human exposure and whether standard bacterial water quality monitoring practices adequately account for this potential threat. Beach water and sand samples were analyzed during summer months for S. aureus, enterococci, and MRSA at three southern California beaches (Avalon, Doheny, Malibu Surfrider). S. aureus frequently was detected in samples of seawater $(59 \%, n=328)$ and beach sand $(53 \%, n=358)$. MRSA sometimes was detected in seawater $(1.6 \%, n=366)$ and sand $(2.7 \%, n=366)$ at relatively low concentrations. Site specific differences were observed, with Avalon Beach presenting the highest concentrations of S. aureus and Malibu Surfrider the lowest in both seawater and sand. S. aureus concentrations in seawater and sand were correlated to each other and to a variety of other parameters. Multiple linear regression on the combined beach data indicated that significant explanatory variables for S. aureus in seawater were S. aureus in sand, water temperature, enterococci in seawater, and the number of swimmers. In sand, S. aureus concentrations were related to S. aureus in seawater, water temperature, enterococci in seawater, and inversely to surf height classification. Only the correlation to water temperature held for individually analyzed beaches and for S. aureus concentrations in both seawater and sand. To provide context for these results, the prevalence of $S$. aureus in sand was compared to published fomite studies, and results suggested that beach prevalence was similar to that in homes.
\end{abstract}

Published by Elsevier Ltd.

\section{Introduction}

Microbial contamination of marine waters worldwide is estimated to cause millions of gastrointestinal and acute respiratory infections (ARIs) (Shuval, 2003) and numerous skin infections (Yau et al., 2009) every year. Marine-borne pathogens in the US cost over $\$ 900$ million per year, with $\$ 300$ million from gastrointestinal illness from beach recreation (Ralston et al., 2011). Marine-related food-borne illness from Staphylococcus aureus was estimated at less than $\$ 500,000$ per

\footnotetext{
Abbreviations: CHROMagar ${ }^{\mathrm{TM}}$ Staph aureus (SCA), fecal indicator bacteria (FIB).

* Corresponding author. Tel.: +1 858546 7142; fax: +1 8585467003.

E-mail address: kelly.goodwin@noaa.gov (K.D. Goodwin).

${ }^{1}$ Stationed at SWFSC, La Jolla, CA 92037, USA.
} 0043-1354/\$ - see front matter Published by Elsevier Ltd. doi:10.1016/j.watres.2012.04.001

This article is a U.S. government work, and is not subject to copyright in the United States. 
year; unfortunately, data were not available to consider costs due to skin infections.

S. aureus is an opportunistic pathogen carried by $20-40 \%$ of people (Al-Zu'Bi et al., 2004 Kluytmans and Wertheim, 2005; Kuehnert et al., 2006) with an estimated $\sim 0.8 \%$ of the US population $(\sim 2.3$ million people) colonized by MRSA (Kuehnert et al., 2006). Incidence of infection from hospitaland community-onset $S$. aureus and MRSA is on the rise worldwide (Chambers, 2001; Zetola et al., 2005). Unlike typical hospital-associated strains, some strains of communityassociated S. aureus can cause infections in healthy people with no traditional risk factors for infection (Chambers, 2001; Baba, 2002; Eguia and Chambers, 2004; Mulvey et al., 2005; Gorwitz, 2008). Even though most patients are treated as outpatients, hospitalization rates remain substantial (Kuehnert et al., 2005; Jarvis et al., 2007). The proportion of skin and soft tissue infections caused by MRSA has risen substantially (Moran et al., 2005), and drug resistant infections place an additional \$5 billion burden on the United States health care system annually (Zhang et al., 2011).

Beaches have been suggested as a potential source of community-acquired S. aureus infection (Charoenca and Fujioka, 1995; Soge et al., 2009). Support for this suggestion derives from concentrations of $\mathrm{S}$. aureus and total staphylococci being correlated to GI illness and to skin, eye and ear infections among bathers (Seyfried et al., 1985; Calderon et al., 1991; Gabutti et al., 2000). S. aureus and MRSA are shed by swimmers (Robinton and Mood, 1966; Hanes and Fossa, 1970; Smith and Dufour, 1993; Elmir et al., 2007; Plano et al., 2011), and both are found in beach seawater and sand (Goodwin and Pobuda, 2009; Soge et al., 2009; Sinigalliano et al., 2010; Shah et al., 2011; Enns et al., 2012). S. aureus concentrations have been correlated to bather density and attributed to human activity (Calderon et al., 1991; Charoenca and Fujioka, 1995; Papadakis et al., 1997; World Health Organization, 2003).

It has been suggested that human activity is the source of $S$. aureus at the beach (El-Shenawy, 2005). However, S. aureus also is found in stormwater (Selvakumar and Borst, 2006) and in coastal streams that drain to the coast (Viau et al., 2011), and wastewater may be another source of S. aureus to the environment. Although some studies have not found viable cells or genetic signatures in treated municipal wastewater (Volkmann et al., 2004; Shannon et al., 2007), other studies have found viable S. aureus and MRSA in raw (Ahtiainen et al., 1991; Rusin et al., 2003; Börjesson et al., 2009, 2010; Goldstein, 2010) and secondary treated wastewater (Goldstein, 2010). In addition to human inputs, domestic pets can be reservoirs for S. aureus and MRSA (Malik et al., 2006; Weese et al., 2006; Nuttall et al., 2008; Baptiste et al., 2009), and dogs can be significant contributors of fecal indicator bacteria (FIB), to the beach (Wright et al., 2009; Zhu et al., 2011).

In an effort to reduce human exposure to microbial contaminants, recreational waters are monitored for FIB, such as enterococci (USEPA, 2004; Dorman and Stoner, 2007). In turn, beach closures can be costly; for example, a 4-month closure of a Southern California beach resulted in millions of dollars of lost revenue, and almost 2 million dollars was spent in closure investigation fees (Dwight et al., 2005). Despite the investment in FIB monitoring, there are concerns that it may overlook pathogens that are not primarily associated with feces (such as S. aureus), and that a complementary indicator may be warranted (Cheung et al., 1990). Staphylococci have been suggested as an alternative or complementary indicator for marine water quality (Seyfried et al., 1985; Cheung et al., 1990; Gabutti et al., 2000).

An additional concern is that current FIB guidelines do not monitor the concentrations of bacteria in beach sands, and concern is growing with regard to this exposure route (Heaney et al., 2009; Yamahara et al., 2009; Hartz et al., 2010; Halliday and Gast, 2011; Phillips et al., 2011; Shibata and SoloGabriele, 2012). There also is concern that even dead and injured cells deposited to the environment from treated wastewater may pose a threat because antibiotic resistance genes can be taken up by live bacteria (Ahtiainen et al., 1991; Martinez, 2009; Börjesson et al., 2009, 2010). The transfer of mecA genes, which confers resistance to methicillin and other beta-lactam antibiotics, is thought to be relatively rare; however, as the abundance of mecA DNA has increased in the environment, the chance of transfer has increased (Chambers, 2001).

In this study, the prevalence and concentration of $S$. aureus and MRSA were studied in both seawater and beach sand. Results were compared to enterococci seawater concentrations and environmental parameters. Correlation, regression and multivariate statistical analyses were performed to identify parameters descriptive of the measured bacterial concentrations and to explore whether FIB monitoring might reflect concentrations of $S$. aureus (a non-fecal pathogen) and whether FIB and pathogens might share conditions suggestive of environmental persistence. The study represents a large collection of samples analyzed for $\mathrm{S}$. aureus and MRSA from beach water $(>320)$ and sand $(>350)$ taken on 89 different sampling days.

\section{Materials and methods}

\subsection{Sample collection, processing, and bacterial identification}

Samples of sand and seawater were collected from beaches at Avalon, Doheny, and Malibu Surfrider beaches in California. Bulk water samples were collected as part of the Pacific Coast Water Study and processed as described previously in Converse et al. (2012). Processing of samples for S. aureus analysis was as described in Goodwin and Pobuda (2009) for Avalon and Doheny beaches. In addition, samples of seawater (40-300 ml) or sand ( 120 g) were collected from Malibu Surfrider beach from May to September in 2009. A total of 12 beach sites, excluding sites in the lagoons at Malibu and Doheny, were tested on 89 different sampling days during the summers of 2007-2009. At Avalon (Fig. 1) samples were collected on 46 different days; sites A, B, and C were tested in both 2007 and 2008, whereas site D (Descanso Beach; separate watershed with less commercial development) was tested only in 2008. For Malibu Beach (Fig. 1), samples were collected on 38 different days. Malibu sites A and B were near the lagoon outlet, and Site A also was near a housing development on septic system. Only a small number of samples were successfully processed for S. aureus from Doheny Beach (5 




Fig. 1 - Aerial photos of Avalon and Malibu beaches (available from google.com) with sample sites depicted. Doheny beach is not shown because data from only one site is presented herein.

sampling days) and from lagoon sites (e.g., between Malibu Sites A and B; Fig. 1) due to overgrowth of non-target colonies; data from lagoon sites were not included in the analysis here.

Filtered samples of water were incubated either on CHROMagar $^{\text {TM }}$ Staph aureus (SCA) or CHROMagarTM MRSA (BD
Biosciences, San Jose, CA, USA) at $37^{\circ} \mathrm{C}$ for $24 \mathrm{~h}$ for SCA and $48 \mathrm{~h}$ for CHROMagar ${ }^{\mathrm{TM}}$ MRSA. Plates were refrigerated overnight prior to counting to allow for better color development. No enrichment or recovery step was used in this study. Putative S. aureus colonies were counted, and typically all or 
sometimes a representative number of colonies ( $\sim 50 \%)$ was picked, streaked for isolation, and incubated as described above to confirm/adjust the initial count. Isolates were identified as $S$. aureus or MRSA through a combination of morphology and PCR as previously described (Goodwin and Pobuda, 2009). Briefly, S. aureus was identified on SCA or CHROMagarTM MRSA plates as a mauve colony with matte halo. For the study here, 3360 colonies were streaked for isolation to determine morphology and 846 isolates were checked by PCR. Previous work (Goodwin and Pobuda, 2009) showed that combined filter and isolate appearance with these seawater and sand samples provided a good balance between sensitivity and specificity, with a positive $\%$ agreement (sensitivity), a negative \% agreement (specificity), and \% positive predictive accuracy of $84 \%, 95 \%$, and $99 \%$, respectively (Goodwin and Pobuda, 2009).

PCR confirmation of isolate identity utilized primers to amplify the clfA gene (ClfA-F, 5'-GCAAAATCCAGCACAACAGGAAACGA-3'; ClfA-R, 5'-CTTGATCTCCAGCCATAAT TGGTGG-3') (Mason et al., 2001) (Fig. 2A) and some samples also were tested for the presence of the staphylococcal 16S rRNA gene (Mason et al., 2001). For colonies isolated from CHROMagarTM MRSA and that were positive for $S$. aureus by PCR, MRSA confirmation utilized primers to amplify the mecA gene (mecA-F, 5'-TCCAGGAATGCAGAAAGACCAAAGC-3';

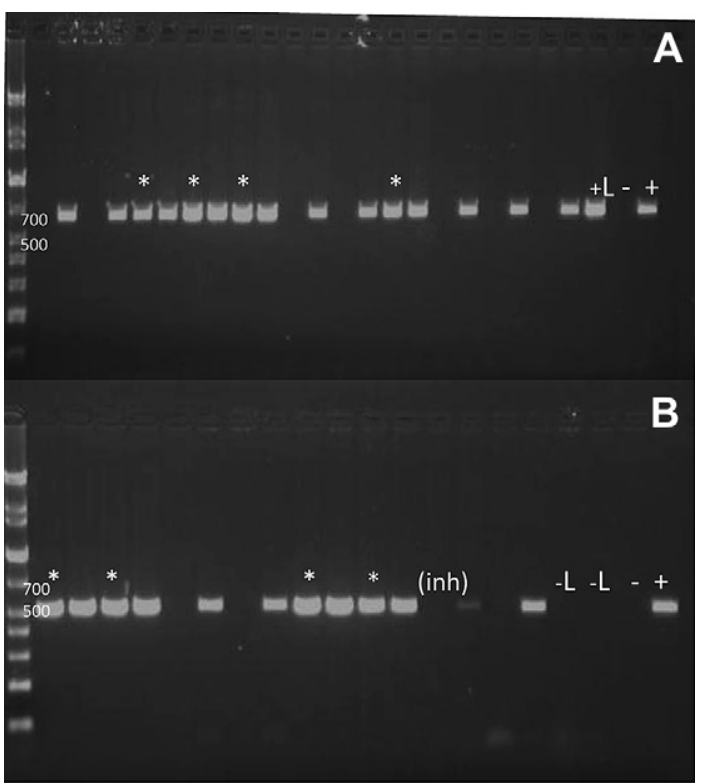

Fig. 2 - Agarose gel electrophoresis photos for bacteria isolated from Avalon beach and amplified with A) clfA primers or B) mecA primers. Pairs of wells contain sample amplicon and the corresponding inhibition control (sample plus spike of positive control DNA). * represents a positive sample, (inh) represents a partially inhibited sample, - represents a no template control, + represents a positive DNA control, $+\mathrm{L}$ represents a crude lysate from a $S$. aureus colony, and $-\mathrm{L}$ represents $\mathrm{S}$. aureus crude lysate, however the culture was not MRSA, therefore, no mecA amplicon was expected. The first lane of each gel contains a DNA ladder with the 500 and 700 bp bands identified.
mecA-R, 5'-GACACGATAGCCATCTTCATGTTGG-3') (Mason et al., 2001; Goodwin and Pobuda, 2009) (Fig. 2B). Amplification reactions were carried out using $1 \mathrm{X}$ Phusion ${ }^{\text {TM }}$ HF Buffer (containing $1.5 \mathrm{mM} \mathrm{MgCl}_{2}$ ), $0.2 \mathrm{mM}$ dNTPs (BioRad), $0.5 \mu \mathrm{M}$ of each primer, $0.3 \mathrm{mg} / \mathrm{ml}$ bovine serum albumin (BSA), $0.5 \mu \mathrm{l}$ (1 U) Finnzymes Phusion Hot Start High Fidelity DNA Polymerase (NEB, Ipswich, MA), $1 \mu$ l of cell colony lysate, and nuclease-free water for a final volume of $50 \mu \mathrm{l}$. Amplification conditions were as follows: $98^{\circ} \mathrm{C}$ for $30 \mathrm{~s}$; 35 cycles of $98^{\circ} \mathrm{C}$ for $5 \mathrm{~s}, 60^{\circ} \mathrm{C}$ for $10 \mathrm{~s}, 72^{\circ} \mathrm{C}$ for $15 \mathrm{~s}$; a final 8 min extension at $72{ }^{\circ} \mathrm{C}$. Inhibition controls consisted of a sample reaction spiked with positive control DNA $(0.5 \mu \mathrm{l}$ of $10 \mathrm{pg} / \mu \mathrm{l}$ stock). The presence of an inhibition control band but not a sample band was used to verify negative reactions (Fig. 2). Inhibited samples were diluted 1:5 and re-run to verify the negative reaction. Positive controls consisted of a DNA control and crude lysate control as described in Goodwin and Pobuda (2009).

\subsection{Data analysis}

Two main types of data analysis were conducted: i) descriptive statistics to explore general frequency and trend results at the study sites and ii) correlation and regression analyses to explore relationships between $\mathrm{S}$. aureus, enterococci, and other non-microbial parameters measured in the study. To best deal with samples below the limit of detection ("nondetects") and varying detection limits, statistical methods specially designed to handle censored data were used (Helsel, 2005). This method is regarded as superior to value substitution for nondetects in data analysis (Helsel, 2010). For comparison with the censored data approach, data were analyzed with standard linear regression using traditional value substitution for nondetects (referred as non-censored data hereon).

\subsubsection{Descriptive statistics}

Percent frequency of detection described the percentage of samples positive for S. aureus, enterococci, or MRSA; calculated as the number samples with one or more target colonies out of the total number of samples in which countable data was obtained for that target. The mean, standard error, standard deviation, median, confidence intervals, and percentiles of S. aureus and enterococci concentrations were computed using the nonparametric Kaplan-Meier method with Efron bias correction via the macros \%KMSTATS and \% BootKM for Minitab ${ }^{\circledR} 16$ software (available at www. practicalstats.com). These macros adapted the Kaplan-Meier method to deal with nondetects (left-censored data) by flipping the data to right-censored before calculation (Helsel, 2005). Descriptive statistics also were calculated by ROS estimation with the macro \%bootros; however, results were equivalent so only the Kaplan-Meier statistics were presented here.

The median detection limit for S. aureus was $0.67 \mathrm{CFU} /$ $100 \mathrm{ml}$ (range 0.33-4 CFU/100 ml), and the median detection limit for enterococci was $1 \mathrm{CFU} / 100 \mathrm{ml}$ (range 1-100 CFU/ $100 \mathrm{ml})$. Nondetects with a detection limit greater than $2 \mathrm{CFU} /$ $100 \mathrm{ml}$ for $\mathrm{S}$. aureus and $4 \mathrm{CFU} / 100 \mathrm{ml}$ for enterococci were removed for calculation and comparison of descriptive statistics. This removed 8 data points for $S$. aureus ( 6 from Doheny, 2 
from Avalon 2008) and 5 for enterococci (3 from Doheny, 2 from Avalon 2007). The actual detection limit for each sample was otherwise utilized. No values were removed from the sand data (the typical detection limit was 3.03 CFU/100 dry g). For MRSA data, the number of nondetects was greater than $50 \%$, rendering the descriptive statistics of limited value due to high uncertainty. Therefore, MRSA data were described in terms of the $\%$ of samples above threshold and the $95 \%$ upper confidence limit (UCL) for the mean (Helsel, 2005).

Median concentrations for $S$. aureus and enterococci for three or more groups of censored data were compared using a Kruskal-Wallis multiple comparison testing using the \% censKW macro with an alpha 0.05 subcommand. Comparisons between two groups of censored data used a Mann Whitney-U test by executing the \%censMW macro. Censored boxplots were generated using the \%cbox macro.

\subsubsection{Correlation and regression analyses}

Relationships between S. aureus, enterococci, and other nonmicrobial parameters were explored via simple correlation/ regression and multiple linear regression analyses. In general, a bacterial concentration (S. aureus in seawater, S. aureus in sand, or enterococci in seawater) was compared to the set of remaining variables. The following continuous variables were utilized: 1) S. aureus seawater concentration (ln CFU/L); 2) S. aureus sand concentration (ln CFU/100 g dry sand); 3) enterococci seawater concentration (ln CFU/L); 4) water temperature $\left({ }^{\circ} \mathrm{C}\right)$; 5) number of swimmers counted during sampling; 6) number of persons with water contact determined via questionnaire; 7) number of dogs; 8) number of birds; 9) tide (m). The following ordinal variables were utilized: 10) surf height classification ( $0=$ none; $0.76=$ low, $0.3-0.9 \mathrm{~m} ; 1.5=$ moderate, $1.2-1.8 \mathrm{~m}$; high $=2.1+\mathrm{m}) ; 11)$ wind classification $(0=$ none; 1 = light; 2 = moderate; 3 = strong); and 12) turbidity classification $(0=$ clear; $1=$ calm; 2 = slightly turbid; $3=$ choppy; $4=$ turbid). Data were analyzed per individual beach and for the combined data. In addition, analysis of Malibu Surfrider beach included berm flow ( $0=$ open; $1=$ closed).

First, simple correlation was used to test association between two variables: a bacterial concentration of interest and another variable (see above). The nonparametric Kendall's tau correlation coefficient and test of significance was calculated using the macro \%Ckend for Minitab ${ }^{\circledR} 16$ software (Helsel, 2005). The Kendall's tau analysis used a rank-based measure of association and allowed one or both variables to include nondetects, multiple detection limits, and required no assumption about the distribution of the data. The macro returned values for both tau a and tau-b (which ignores ties) in a range of -1 to 1 , with a zero value supporting the null hypothesis of no correlation between the variables. One advantage of a Kendall tau test was that it generated a $p$-value, which tested whether the value was significantly different from zero. For comparison, the Kendall tau value runs about 0.2 lower than a Pearson's $r$ value for an equivalent strength of correlation (D. Helsel, personal communication). The nonparametric regression line associated with the Kendall's tau, the Akrita-Theil-Sen (ATS) line, was calculated using the \%ATS macro command (Helsel, 2005).

Next, multiple linear regression was conducted between one dependent and multiple independent variables (described above) to obtain a best-fit model describing bacterial concentrations. The goal of the regression analysis was descriptive so interaction and nested terms were not evaluated. Regression with censored data was performed using the Minitab ${ }^{\circledR} 16$ option for regression with life data (arbitrary censored option) and maximum likelihood estimation (MLE). Model selection was based on $p$-values for the coefficients (typically $\alpha=0.01$ ), with insignificant terms sequentially removed. Models with significant terms were further evaluated using the likelihoodratio test which compared the model to the null using the equation $-2 \times$ (log-likelihood of the null model - log-likelihood of model); test statistics with $p$-values less than 0.01 were considered significant. Test statistic $p$-values were calculated via the chi-square distribution with the degrees of freedom equal to the number of estimated coefficients in the model subtracted by the number of estimated coefficients in the null model, as per Minitab ${ }^{\circledR}$ instructions.

In addition, typical regression analysis with non-censored data (i.e., value substitution) also was performed. This analysis returned information regarding model fit including residual plots, Anderson-Darling statistics, and variance inflation factors to identify multi-co-linearity. Furthermore, principal component analysis, stepwise regression, and best subset analysis was performed to help understand the data structure and to inform and confirm results from the multiple linear regression analysis. Additionally, the distributions of S. aureus in sand and seawater and of enterococci in seawater were analyzed using both censored and non-censored data, with output including probability plots and goodness-of-fit tests.

\section{Results \\ 3.1. Microbe detection frequency and concentrations at the study sites}

\subsubsection{S. aureus in seawater}

S. aureus was frequently detected in seawater. The average \% detection frequency for seawater was $59 \%(n=328)$ for the combined beaches (Table 1). For Avalon, the average \% detection frequency was $76 \%$ for the two summers studied. For Malibu Surfrider, the average \% detection frequency was $46 \%$. Only eight Doheny seawater samples were successfully enumerated for S. aureus due to overgrowth of plates, and all were positive for S. aureus (100\%). The mean concentration of S. aureus in the seawater samples estimated by Kaplan-Meier statistics was $10 \mathrm{CFU} / 100 \mathrm{ml}$ and the median concentration was $0.83 \mathrm{CFU} / 100 \mathrm{ml}$, with data for individual beaches given in Table 1.

Kruskal-Wallis multiple comparisons tests $(\alpha=0.05)$ showed that the median seawater concentration of S. aureus was significantly lower at Malibu Surfrider compared to the other beaches (Fig. 3). Within Malibu, the four beach sites (Fig. 1) had similar seawater concentrations (although site B was significantly lower than site D). Site A, with presumed septic influence, was not significantly different from any of the other sites. Within Avalon, the four beach sites (Fig. 1) also were similar to one another (although Site B in 2008 was significantly higher than Site C in 2007). Overall, S. aureus at Avalon was significantly higher in 2008 than 2007 (7.5 versus 
Table 1 - Detection frequency and concentration of S. aureus and MRSA in seawater and sand. NC = not calculated.

\begin{tabular}{|c|c|c|c|}
\hline Site & S. aureus & Enterococci & MRSA \\
\hline \multicolumn{4}{|c|}{ Detection frequency seawater } \\
\hline All & $59 \%$ & $79 \%$ & $1.6 \%$ \\
\hline \multicolumn{4}{|c|}{ Concentration seawater (CFU/100 ml) } \\
\hline & $\begin{array}{l}\text { Mean }(95 \% \mathrm{CI}) \\
\text { median }(n)\end{array}$ & $\begin{array}{l}\text { Mean }(95 \% \text { CI); } \\
\text { median }(n)\end{array}$ & $\begin{array}{l}95 \% \text { UCL of mean; } \\
\text { range observed }(n)\end{array}$ \\
\hline All & $\begin{array}{l}10(7.3-15) \\
0.83(n=328)\end{array}$ & $\begin{array}{l}42(28-59) \\
6(n=331)\end{array}$ & $\begin{array}{l}0.65 \\
0.33-2.5(n=366)\end{array}$ \\
\hline Avalon & $\begin{array}{l}23(15-33) \\
5.0(n=132)\end{array}$ & $\begin{array}{l}68(45-105) \\
30(n=132)\end{array}$ & NC \\
\hline Doheny & $\begin{array}{l}5.3(2.7-7.9) \\
4.0(n=8)\end{array}$ & $\begin{array}{l}148(15-388) \\
20(n=11)\end{array}$ & NC \\
\hline Malibu & $\begin{array}{l}1.8(1.3-2.5) \\
0.69(n=188)\end{array}$ & $\begin{array}{l}17(8.8-27) \\
2.0(n=188)\end{array}$ & NC \\
\hline \multicolumn{4}{|c|}{ Detection frequency sand } \\
\hline All & $53 \%$ & $71 \%$ & $2.7 \%$ \\
\hline \multicolumn{4}{|c|}{ Concentration sand (CFU/100 dry g) } \\
\hline & $\begin{array}{l}\text { Mean }(95 \% \mathrm{CI}) \text {; } \\
\text { median }(n)\end{array}$ & $\begin{array}{l}\text { Mean }(95 \% \mathrm{CI}) \\
\text { median }(n)\end{array}$ & $\begin{array}{l}95 \% \text { UCL of mean; } \\
\text { range observed }(n)\end{array}$ \\
\hline All & $\begin{array}{l}187(98-390) \\
7.7(n=358)\end{array}$ & $\begin{array}{l}5086(3331-10,755) \\
13(n=238)\end{array}$ & $\begin{array}{l}2.5 \\
5-78(n=366)\end{array}$ \\
\hline Avalon & $\begin{array}{l}402(192-830) \\
111(n=159)\end{array}$ & $\begin{array}{l}24,009(16,197-47,930) \\
3198(n=49)\end{array}$ & $\mathrm{NC}$ \\
\hline Doheny & $\begin{array}{l}58(37-117) \\
25(n=11)\end{array}$ & $\begin{array}{l}8646(1146-16222) \\
3976(n=5)\end{array}$ & NC \\
\hline Malibu & $\begin{array}{l}21(12-40) \\
4.9(n=188)\end{array}$ & $\begin{array}{l}54(39-75) \\
12(n=184)\end{array}$ & NC \\
\hline
\end{tabular}

3.0 CFU/100 ml median concentration, $\alpha=0.05)$. Except for Site $\mathrm{B}$ in 2008 , Site D was not lower than the other sites, even though Site D was envisioned as a control site because it was located in a different watershed with less commercial development adjacent to the beach (Fig. 1). There was only one beach site sampled at Doheny beach, thus no site comparisons were possible.

\subsubsection{Enterococci in seawater}

Enterococci concentrations are presented only for samples in which S. aureus analysis also was conducted. Enterococci were frequently detected in seawater, with an average \% detection frequency of $79 \%(n=331)$ for the beaches combined (Table 1$)$. For Avalon, the average \% detection frequency for seawater was $88 \%$ for both summers. At Malibu Surfrider, the average $\%$ detection frequency was $72 \%$. Only eleven Doheny seawater samples had corresponding S. aureus data; all of them were positive for enterococci $(100 \%)$. The mean concentration of enterococci in all the seawater samples estimated by Kaplan-Meier statistics with Efron bias correction was $42 \mathrm{CFU} / 100 \mathrm{ml}$ and the median concentration was $6 \mathrm{CFU} /$ $100 \mathrm{ml}$, with data for individual beaches given in Table 1.

Kruskal-Wallis multiple comparisons tests $(\alpha=0.05)$ showed that the median seawater concentration of enterococci was significantly lower at Malibu compared to the other beaches (Fig. 3). At Malibu, the median enterococci concentration at site A (with presumed septic influence) was significantly lower than sites B and E, but did not differ significantly from Site D. At Avalon, median seawater concentrations of enterococci were not statistically different between 2008 and
2007, in contrast to S. aureus. At Avalon, the median enterococci concentration at Site A in 2008 was significantly lower than sites B and C in both 2007 and 2008, despite the fact that the sites were located close to one another (Fig. 1).

\subsubsection{S. aureus in sand}

S. aureus was frequently detected in beach sand, similar to that observed for seawater. The average \% detection frequency was $53 \%(n=358)$ for the combined beach data (Table 1). For Avalon, the average \% detection frequency was $62 \%$ for both years combined. For Malibu Surfrider, the average $\%$ detection frequency was $46 \%$ for sand. Although only a few samples were successfully analyzed for Doheny beach $(n=11)$, the detection frequency was similar to that observed at the other beaches (45\%). The mean concentration of $S$. aureus in the sand samples estimated by Kaplan-Meier statistics with Efron bias correction was 187 CFU/100 dry g and the median concentration was $7.7 \mathrm{CFU} / 100 \mathrm{dry} g$, with data for individual beaches given in Table 1.

Kruskal-Wallis multiple comparisons tests $(\alpha=0.05)$ showed that the median concentration of $S$. aureus in sand was lower at Malibu than at Avalon (Fig. 3). Concentrations of S. aureus in sand were higher at Avalon in 2008 than in 2007, as was found for the seawater concentrations. No significant differences among individual beach sites were observed for Avalon or Malibu.

\subsubsection{Enterococci in sand}

Enterococci concentrations are presented only for those samples which also had collection for S. aureus analysis. The 

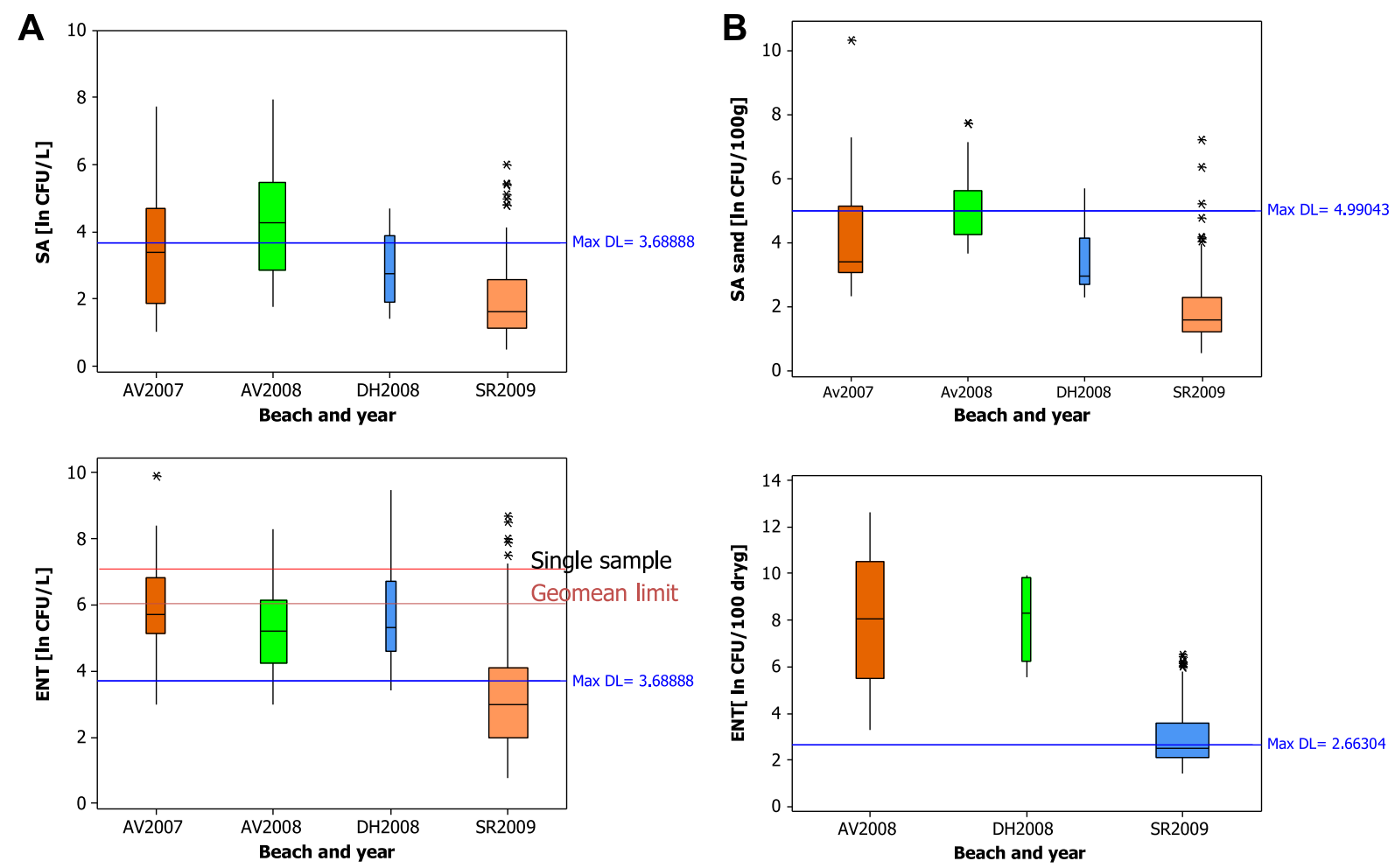

Fig. 3 - Box plots of S. aureus (SA) and enterococci (ENT) concentrations in A) seawater and B) sand generated by Kruskal-Wallis analysis $(\alpha=0.05)$ for samples collected from beach sites in Avalon during 2007 (AV2007) and 2008 (AV2008), Doheny in 2008 (DH2008), and Malibu Surfrider in 2009 (SR2009). Box width is proportional to sample size. Horizontal lines depict the maximum detection limit (Max DL) for the data. For enterococci in seawater, the EPA recreational water quality guidelines for a single sample and the geometric mean (Geomean limit) also are shown.

average $\%$ detection frequency was $71 \%(n=238)$ for the combined beaches (Table 1). For Avalon (2008), the average \% detection frequency was $94 \%(n=49)$. Enterococci concentrations in terms of CFU/dry g sand were not available for Avalon in 2007. For Malibu Surfrider, the average \% detection frequency was $63 \%$. Only five Doheny sand samples had corresponding S. aureus data; all of them were positive for enterococci (100\%). The mean concentration of enterococci in sand samples estimated by Kaplan-Meier statistics with Efron bias correction was 5086 CFU/100 dry g and the median concentration was $13 \mathrm{CFU} / 100$ dry g, with data for individual beaches given in Table 1 .

Kruskal-Wallis multiple comparisons tests $(\alpha=0.05)$ showed that the median concentration of enterococci in sand at Malibu was significantly lower than at the other beaches tested (Fig. 3). No significant differences across beach sites were observed except that the median enterococci concentration in sand at Malibu (Fig. 1) was significantly lower at Site E than Site B.

\subsubsection{MRSA in seawater and sand}

MRSA was found on occasion in seawater and sand at relatively low concentrations. Of the 12 beach sites tested, the overall \% detection frequency was $1.6 \%$ (6/366) for seawater and $2.7 \%$ (10/ 366) for sand (Table 1). The \% detection frequency varied by beach with Avalon having the highest frequency of detection for seawater $(3.8 \%, 5 / 131)$ and sand $(5.9 \%, 8 / 136)$. In contrast, the $\%$ detection frequency at Malibu was $0.4 \%$ (1/224) for seawater and $0.5 \%$ (1/221) for sand. No seawater samples were positive for MRSA at Doheny $(n=14)$ but $14 \%(1 / 7)$ were positive in the sand. Greater than $50 \%$ of the samples were nondetects; therefore, the concentration data are presented in terms of the 95\% upper confidence limit (UCL) (Helsel, 2005) along with the range of concentrations observed (Table 1). The 95\% UCL indicates that there was only a $5 \%$ chance of encountering a concentration higher than that given in Table 1.

\subsubsection{Enterococci concentrations relative to $\mathrm{S}$. aureus}

Enterococci concentrations were higher than S. aureus in both seawater and sand. For seawater, the ratio of enterococci to $S$. aureus was fairly consistent across beaches and generally less than an order of magnitude. The median seawater concentration of enterococci was $7 \times$ higher than S. aureus for the combined beaches, ranging from $3-6 \times$ higher for the individual beaches. For sand, the ratio of enterococci to $S$. aureus was more variable. The median sand concentration of enterococci was $2 \times$ higher than $S$. aureus for the beaches combined, but the range across beaches was $2-159 \times$.

\subsection{Relationships between S. aureus, enterococci, and} non-microbial parameters measured in the study

\subsubsection{Simple correlations and simple linear regression} Kendall tau analysis and simple linear regression with life data were comparable and showed that $S$. aureus concentrations in seawater and in sand were correlated to a number of 
the analyzed variables (Table 2). S. aureus concentrations in seawater and sand were strongly correlated to each other (Table 2). Both seawater and sand concentrations were correlated to water temperature, the seawater concentration of enterococci, and surf height classification (inversely correlated). In addition, S. aureus in seawater (but not in sand) was significantly correlated with the number of swimmers as determined by observation at the time of collection. S. aureus concentrations were not correlated to the number of people having water contact as determined by questionnaire, although this was the parameter used in subsequent epidemiology analysis (Colford et al., 2012). S. aureus in sand (but not seawater) was inversely correlated to wind strength classification. Wind, tide height, and turbidity all became significant at $\alpha=0.05$ (Table 2). Only water temperature and the number of swimmers were significantly correlated to the S. aureus concentration in seawater for both the combined beach data and for Avalon and Malibu beaches analyzed separately (Table 2). Doheny beach was not analyzed separately due to the small sample size. Other significant correlations for individual beaches are given in Table 2.

Table 2 - Results of analyses by Kendall tau correlation and simple linear regression with life data, each calculated for one dependent ( $S$. aureus concentration in seawater or sand) and one independent variable for the combined beach data. Coefficients are given from the Akritas-Theil-Sen (ATS) line of the Kendall tau analysis and from MLE (in parenthesis) for significant $p$-values $(\alpha=0.01)$. NS $=$ not significant.

\begin{tabular}{|c|c|c|}
\hline & \multicolumn{2}{|c|}{ Dependent variable } \\
\hline & $\begin{array}{l}\text { Seawater } \\
\text { S. aureus } \\
\text { (ln CFU/L) }\end{array}$ & $\begin{array}{c}\text { Sand } \\
\text { S. aureus } \\
\text { (ln CFU/100 dry g) }\end{array}$ \\
\hline $\begin{array}{l}\text { Independent } \\
\text { variable }\end{array}$ & Coefficient from & ATS line (from MLE) \\
\hline $\begin{array}{l}\text { S. aureus sand } \\
\text { (ln CFU/100 dry g) }\end{array}$ & $0.67(0.63)^{b}$ & - \\
\hline $\begin{array}{l}\text { S. aureus seawater } \\
(\ln \mathrm{CFU} / \mathrm{L})\end{array}$ & - & $0.81(0.72)$ \\
\hline $\begin{array}{l}\text { Water temperature } \\
\left({ }^{\circ} \mathrm{C}\right)\end{array}$ & $0.66(0.62)^{\mathrm{a}}$ & $0.68(0.64)$ \\
\hline $\begin{array}{l}\text { Enterococci } \\
\qquad(\ln \mathrm{CFU} / \mathrm{L})\end{array}$ & $0.49(0.44)$ & $0.64(0.59)$ \\
\hline $\begin{array}{l}\text { Surf height } \\
\text { classification (m) }\end{array}$ & $-1.4(-1.4)$ & $-0.94(-2.0)$ \\
\hline $\begin{array}{l}\text { \#Swimmers } \\
\text { (counted) }\end{array}$ & $0.046(0.028)^{a}$ & NS \\
\hline $\begin{array}{l}\text { \# Swimmers } \\
\text { (reported) }\end{array}$ & NS & NS \\
\hline Wind classification & $\mathrm{NS}^{\mathrm{c}}$ & $-1.18(-0.92)$ \\
\hline Tide height (m) & $\mathrm{NS}^{\mathrm{c}}$ & $\mathrm{NS}^{\mathrm{c}}$ \\
\hline Turbidity classification & $\mathrm{NS}^{\mathrm{c}}$ & $\mathrm{NS}^{\mathrm{c}}$ \\
\hline Birds (\#) & NS & NS \\
\hline Dogs (\#) & NS & NS \\
\hline
\end{tabular}

Kendall tau analysis was useful for comparing concentrations of bacteria because it could account for nondetects in both variables and made no assumptions about distribution shape. For the combined beach data, the relationship between the $S$. aureus concentration in seawater and sand was described by the following ATS line: S. aureus $(\ln \mathrm{CFU} / \mathrm{L})=0.18+0.67 \times \mathrm{S}$. aureus (ln CFU/100 dry g) (tau-b $=0.29, p<0.001$ ). With the concentration in sand as the dependent variable, the relationship was described by the following ATS line: S. aureus (ln CFU/ $100 \mathrm{dry} g$ sand $)=0.053+0.81 \times \mathrm{S}$. aureus $(\ln \mathrm{CFU} / \mathrm{L})($ tau-b $=0.29$, $p<0.001)$. The relationship between the seawater concentrations of S. aureus and enterococci was described by the ATS line S. aureus (ln CFU/L) $=9.30+0.49 \times$ enterococci (ln CFU/ $\mathrm{L}$ seawater) (tau- $\mathrm{b}=0.26, p<0.001$ ). The relationship between the sand concentrations of $S$. aureus and enterococci in seawater was described by the ATS line S. aureus (ln CFU/ 100 dry g sand) $=-0.0061+0.64 \times$ enterococci $(\ln$ CFU/L seawater) (tau-b $=0.27, p<0.001$ ).

For Malibu Surfrider beach, the seawater concentration of $S$. aureus was weakly correlated to whether or not the outlet to the lagoon (Fig. 1, Malibu Site C) was open ( tau-b $=0.18, p=0.01$; open was coded as 0 , therefore the relationship was inverse). There was no significant relationship between seawater enterococci concentration and lagoon flow, and there was no significant relationship between sand S. aureus concentration and lagoon flow. Attempts to quantify S. aureus in the lagoon water were unsuccessful due to overgrowth by non-target bacteria.

Although the focus of this study was S. aureus, a limited number of correlation analyses were performed with enterococci treated as the dependent variable. In addition to the correlation between enterococci and S. aureus described above, the seawater concentration of enterococci was weakly correlated to water temperature for the combined beach data (tau$\mathrm{b}=0.18, p<0.001$ ). However, water temperature was not significantly correlated to enterococci for the individual beaches, in contrast to the findings for S. aureus. The concentration of enterococci was not correlated to the number of swimmers for any of the beaches. It is interesting to note that water temperature was significantly correlated to the number of swimmers for the combined beaches ( tau- $\mathrm{b}=0.25, p<0.001$ ) and for Avalon ( tau-b $=0.35, p<0.001$ ) and Malibu ( tau-b $=0.19, p<0.001$ ) analyzed separately. There was no significant difference in the number of swimmers between beaches (data not shown).

\subsubsection{Multivariate and multiple linear regression analysis results}

Multivariate examination was performed on the combined beach data using principal component analysis. Principal component analysis was consistent with the results obtained by stepwise and best subset regression, and the best description by principal component analysis was obtained with the parameters S. aureus seawater concentration, S. aureus sand concentration, and water temperature (data not shown). Results were consistent with the analyses by Kendall tau and simple linear regression with life data (MLE with one dependent and one independent variable) (Table 2).

The best-fit for MLE analysis for $S$. aureus in sand was obtained using multiple linear regression with life data assuming a lognormal distribution (Table 3; all coefficient $p$-values significant at $\alpha=0.01)$. For $\mathrm{S}$. aureus in seawater, the 
Table 3 - Best-fit multiple linear regression models (MLE with censored data) for S. aureus in beach seawater and sand.

Dependent variable

S. aureus seawater

(ln CFU/L)

S. aureus sand

(ln CFU/100 dry g)
MLE model ${ }^{\mathrm{a}}$

$=-4.6+0.58 \times \mathrm{S}$. aureus (ln CFU/100 dry g sand) $+0.22 \times$ water temperature $\left({ }^{\circ} \mathrm{C}\right)+0.22$

$\times$ enterococci (ln CFU/L seawater) $+0.018 \times$ swimmers (\# counted at time of sample collection)

$=-6.9+0.45 \times \mathrm{S}$. aureus $(\mathrm{ln}$ CFU/L seawater $)+0.37 \times$ water temperature $\left({ }^{\circ} \mathrm{C}\right)+0.24 \times$ enterococci

(ln CFU/L seawater) $+-0.77 \times$ surf height classification $(\mathrm{m})$

a Assumed distribution for S. aureus: lognormal in sand, Weibull in seawater (result for shape parameter, $\beta=0.56$ )

best-fit was obtained using multiple linear regression analysis with life data assuming a Weibull distribution (Table 3; all coefficient $p$-values significant at $\alpha=0.01$, except \# of swimmers at $\alpha=0.03$ ). Variable inflation factors (VIF) revealed moderate colinearity between $S$. aureus concentrations in seawater, enterococci in seawater, S. aureus in sand, and water temperature.

\section{Discussion}

Of the many relationships identified by simple correlation (Table 1), some parameters repeatedly emerged as significant descriptive variables for $\mathrm{S}$. aureus in seawater regardless of analysis methods or approach for nondetects (censored vs. non-censored). These parameters were $S$. aureus sand concentration, water temperature, the number of swimmers, and the enterococci seawater concentration. Of these parameters, water temperature appeared to be particularly salient because it was correlated to $\mathrm{S}$. aureus in both seawater and sand for both the combined data and for beaches analyzed individually (Avalon and Malibu). The only other correlation that held for both combined and individual beach data was the number of swimmers to $S$. aureus in seawater. In addition, the correlation between $S$. aureus concentrations in sand and in seawater held for both the combined data and for Malibu beach analyzed separately.

The correlation between the $\mathrm{S}$. aureus concentration in sand to the concentrations of $S$. aureus and enterococci in seawater supports other studies that suggested beach sands can be a source of both fecal indicator bacteria and pathogens to adjacent waters (Lee et al., 2006; Bonilla et al., 2007; Yamahara et al., 2007, 2009; Goodwin et al., 2009; Halliday and Gast, 2011; Sabinro et al., 2011; Zhu et al., 2011; Shah et al., 2011). Furthermore, studies have implicated sand itself as an important vehicle for human exposure (Whitman et al., 2009) and epidemiology studies indicated that sand can pose a health risk (Bonilla et al., 2007; Heaney et al., 2009, 2012). In contrast to correlations seen between pathogens and indicators in some studies, other studies have found S. aureus to not be correlated to a variety of other indicators (El-Shenawy, 2005), including enterococci (Calderon et al., 1991; Selvakumar and Borst, 2006; Yamahara et al., 2012; Enns et al., 2012). The study here comprised a relatively large data set and days of sampling which may have allowed more patterns to emerge (Table 1). A common sand reservoir for both S. aureus and enterococci perhaps could explain the correlations seen here; however, it should be noted that the correlation existed only for the data combined across beaches but not for the beaches analyzed individually.
The positive correlation of water temperature to S. aureus concentrations in sand and seawater supports the concern that pathogens may grow and/or persist in the environment with sand as a source to adjacent waters, analogous to the case for FIB (Beversdorf et al., 2007; Shah et al., 2011; Phillips et al., 2011). In support of this suggestion, other studies have shown that $S$. aureus and MRSA can survive for days in river and seawater, with better survival in seawater because of a preference for higher salinity (Gabutti et al., 2000; Tolba et al., 2008; Levin-Edens et al., 2011). Both methicillin sensitive $S$. aureus (MSSA) and MRSA can survive on environmental surfaces and are resistant to desiccation (Cimolai, 2008). In addition, the ability for $S$. aureus to be resuscitated from a viable but non-culturable (VBNC) state has been demonstrated (Masmoudi et al., 2010); therefore, survival in sand and seawater appears plausible. Potential to transfer virulence and antibiotic resistance genes also is a concern, particularly if genes may be obtained from wounded or dead organisms contained in treated wastewater (Börjesson et al., 2009, 2010; Goldstein, 2010).

Compared to this study (Table 1), similar detection frequencies for S. aureus and MRSA in seawater $(37 \%$ and $1 \%$, respectively; Sinigalliano et al., 2010) and similar median concentrations (Shah et al., 2011) were reported for a subtropical beach using a substantially smaller data set. During a ten-day intensive study of this same beach, the detection frequency for $\mathrm{S}$. aureus in knee-deep seawater was $19 \%$ and the detection frequency in sand ranged from 0.42 to $10 \%$, depending on the sampling location (Enns et al., 2012). Compared to this study, similar MRSA but lower S. aureus prevalence in sand was observed for a survey of 37 beaches along the entire California coast (prevalence by beach: $13.5 \% \mathrm{~S}$. aureus, 3\% MRSA; Yamahara et al., 2012; prevalence by sample: $8.5 \%$ S. aureus, 1.7\% MRSA; Goodwin unpublished results). Both the California beach survey and this study used the same methodology, but the beach survey investigated only dry sand and included beaches with few visitors (Yamahara et al., 2012); whereas the collections here were all moist sand from beaches with high visitor numbers. S. aureus prevalence in freshwater coastal streams in O'ahu, Hawaii (86\%, 19/22; Viau et al., 2011) was higher than that observed here, with similar concentrations (below detection - $5.2 \mathrm{CFU} / 100 \mathrm{ml}$ for the December sampling; Goodwin unpublished results).

It should be noted that the concentrations here are expected to be biased low despite the positive performance of SCA and C-MRSA with beach water and sand samples (Goodwin and Pobuda, 2009) because the performance only applies to countable plates. In this study, it was often the case that no data were obtained from samples of the poorest water quality because plates were overgrown by non-target 
microbes. Furthermore, it appeared that S. aureus could be outcompeted on the plates by non-target organisms because sometimes it could be identified on less crowded filters but not on more crowded filters that had received a higher volume of water. Therefore, the concentration estimates reported here should be considered conservative.

It should be helpful to view the potential risk from S. aureus and MRSA via beach exposure in context with other exposure routes, such as fomites or food products (Lindenmayer et al., 1998; Scott et al., 1982; Scott et al. 2008; Miller et al., 2009; Scott et al., 2009; Waters et al., 2011). To enable comparison, the concentrations given here can be converted to CFU per area using the specific surface area of coarse sand $\left(\sim 0.01 \mathrm{~m}^{2} /\right.$ g; Yerima and Ranst, 2005), resulting in equivalent concentrations for units in CFU/dry $g$ and CFU $/ \mathrm{m}^{2}$. Given that the typical detection limit for S. aureus in sand was $3.03 \mathrm{CFU} /$ 100 dry g, the frequency of detection for $25 \mathrm{~cm}^{2}$ samples would drop from $53 \%$ to $42 \%$, which is comparable to that reported in homes by Scott et al. (1982) (to express Table 1 sand concentrations in units of CFU/25 $\mathrm{cm}^{2}$, divide values by 400 ).

Ultimately, the significance of $S$. aureus and MRSA prevalence and concentration in the environment depends on the infectious dose (Shibata and Solo-Gabriele, 2012) for both ingestion and, importantly, wound inoculation, particularly under real-world conditions (e.g., multiple organisms and particles contaminating the wound). One study of S. aureus surface inoculation of intact human skin found an $\mathrm{ED}_{50}$ of $10^{3}$ \% $\mathrm{cm}^{2}$, with an inoculation of $40 / \mathrm{cm}^{2}$ causing infection in $20 \%$ of subjects; growth of the organisms after inoculation was necessary to cause infection (Singh et al., 1971; Rose and Haas, 1999). The ability for S. aureus to infect intact skin appeared dependent on a variety of parameters, including initial dose, maintained moisture of the skin surface, and competition with indigenous flora. An inoculation dose lower than $40 / \mathrm{cm}^{2}$ was not tested; however, this dose was almost 1000 times higher than the highest concentration in sand observed here (using the conversion discussed above). However, the infectious dose of $S$. aureus is substantially reduced by factors such as foreign bodies or synergy with other contaminating microbes (Elek, 1956; Schaad, 1983; Brook et al., 1984; Rissing et al., 1987; Hendricks et al., 2001). Both of these modifying conditions could be expected in beach settings, particularly for contamination of a wound with sand. Therefore, obtaining a more accurate assessment of infectious dose under a variety of real-world conditions is an important area for future research. In any case, based on human studies (Singh et al., 1971), rinsing and drying the skin should help provide protection, particularly for intact skin.

\section{Conclusions}

- The frequent detection ( $>50 \%$ ) of $\mathrm{S}$. aureus seawater and beach sand samples and the correlation with water temperature supports the concern that bacterial pathogens exist and may persist in the environment, including at beaches.

- Although the correlation between S. aureus and the number of swimmers was weak and apparent only for S. aureus in seawater and not sand, the correlation held for data analyzed by individual beach and combined across beaches. These data support the possibility that beach goers are one source of this organism but suggests that other sources not identified in this study are important, as well.

- Although the prevalence of MRSA was much lower ( $<3 \%$ of samples) than for S. aureus, the data indicate the potential for virulent and antibiotic resistant strains to be encountered in this environment.

- S. aureus was correlated to enterococci, even though $S$. aureus is not considered a typical fecal organism. Perhaps the finding that $S$. aureus can sometimes be found in wastewater and in companion animal feces explains this observation. However, the relationship held only for the combined beach data, suggesting the need for further study; particularly to ensure whether current FIB guidelines are adequately protective against this pathogen.

\section{Acknowledgements}

We thank the many volunteers and workers of the Pacific Coast Water Study and the laboratory of Dr. Jenny Jay, UCLA, for analysis of enterococci in sand. This research was carried out in part under the auspices of the Cooperative Institute for Marine and Atmospheric Studies (CIMAS), a joint institute of the University of Miami and the National Oceanic and Atmospheric Administration, cooperative agreement \#NA17RJ1226.

\section{R E F E R E N C E S}

Al-Zu'Bi, E., Bdour, S., Shehabi, A.A., 2004. Antibiotic resistance patterns of mecA-positive Staphylococcus aureus isolates from clinical specimens and nasal carriage. Microbial Drug Resistance 10 (4), 321-324.

Ahtiainen, J., Niemi, M., Jousimies-Somer, H.J., 1991. Staphylococci in polluted waters and in waters of uninhabited areas. Water Science and Technology 24 (2), 103-108.

Baba, T., 2002. Genome and virulence determinants of high virulence community-acquired MRSA. Lancet 359, 1819-1827.

Baptiste, K.E., Williams, K., Williams, N.J., Wattret, A., Clegg, P.D., Dawson, S., Corkill, J.E., O'Neill, T., Hart, C.A., 2009. Methicillin-resistant staphylococci in companion animals. Emerging Infectious Diseases 11 (12), 1942-1944.

Beversdorf, L.J., Bornstein-Forst, S.M., McLellan, S.L., 2007. The potential for beach sand to serve as a reservoir for Escherichia coli and the physical influences on cell die-off. Journal of Applied Microbiology 102 (5), 1372-1381.

Bonilla, T.D., Nowosielski, K., Cuvelier, M., Hertz, A., Green, M., Esiobu, N., McCorquodale, D.S., Fleisher, J.M., Rogerson, A., 2007. Prevalence and distribution of fecal indicator organisms in south Florida beach sand and preliminary assessment of health effects associated with beach sand exposure. Marine Pollution Bulletin 54 (9), 1472-1482.

Börjesson, S., Melin, S., Matussek, A., Lindgren, P.E., 2009. A seasonal study of the mecA gene and Staphylococcus aureus including methicillin-resistant $S$. aureus in a municipal wastewater treatment plant. Water Research 43 (4), 925-932.

Börjesson, S., Matussek, A., Melin, S., Löfgren, S., Lindgren, P.E., 2010. Methicillin-resistant Staphylococcus aureus (MRSA) in municipal wastewater: an uncharted threat? Journal of Applied Microbiology 108 (4), 1244-1251. 
Brook, I., Hunter, V., Walker, R.I., 1984. Synergistic effect of Bacteroides, Clostridium, Fusobacterium, anaerobic cocci, and aerobic bacteria on mortality and induction of subcutaneous abscesses in mice. Journal of Infectious Diseases 149 (6), 924-928.

Calderon, R.L., Mood, E.W., Dufour, A.P., 1991. Health effects of swimmers and nonpoint sources of contaminated waters. International Journal of Environmental Health Research 1, 21-31.

Chambers, H.F., 2001. The changing epidemiology of Staphylococcus aureus? Emerging Infectious Diseases 7 (2), 178-182.

Charoenca, N., Fujioka, R., 1995. Association of staphylococcal skin infections and swimming. Water Science and Technology 31, 11-17.

Cheung, W.H.S., Chang, K.C.K., Hung, R.P.S., Kleevens, J.W.L., 1990. Health effects of beach water pollution in Hong Kong. Epidemiology and Infection 105 (1), 139-162.

Cimolai, N., 2008. MRSA and the environment: implications for comprehensive control measures. European Journal of Clinical Microbioloby and Infectious Diseases 27, 481-493.

Colford Jr., J.M., Schiff, K.C., Griffith, J.F., Yau, V., Arnold, B.F., Wright, C.C., Gruber, J.S., Wade, T.J., Burns, S., Hayes, J., McGee, C.D., Gold, M., Cao, Y., Noble, R.T., Haugland, R., Weisberg, S.B., 2012. Using rapid indicators for enterococcus to assess the risk of illness after exposure to urban runoff contaminated marine water. Water Research 46 (7), 2176-2186.

Converse, R.R., Griffith, J.F., Noble, R.T., Haugland, R.A., Schiff, K.C., Weisberg, S.B., 2012. Correlation between quantitative polymerase chain reaction and culture-based methods from measuring enterococcus over various temporal scales and three California marine beaches. Applied and Environmental Microbiology 78 (4), 1237-1242.

Dorman, M., Stoner, N., 2007. Testing the Waters: A Guide to Water Quality at Vacation Beaches, seventeenth ed. Natural Resources Defense Council.

Dwight, R.H., Fernandez, L.M., Baker, D.B., Semenza, J.C., Olson, B.H., 2005. Estimating the economic burden from illnesses associated with recreational coastal water pollution a case study in Orange County, California. Journal of Environmental Management 76 (2), 95-103.

Eguia, J.M., Chambers, H.F., 2004. Community-acquired methicillin-resistant Staphylococcus aureus: epidemiology and potential virulence factors. Current Infectious Disease Reports 5 (6), 459-466.

El-Shenawy, M.A., 2005. Staphylococcus aureus and fecal indicators in Egyptian coastal waters of Aqaba Gulf, Suez Gulf, and Red Sea. Egyptian Journal of Aquatic Research 31 (2), 113-124.

Elek, S.D., 1956. Experimental staphylococcal infections in the skin of man. Annals of the New York Academy of Sciences 65 (3), 85-90.

Elmir, S.M., Wright, M.E., Abdelzaher, A., Solo-Gabriele, H.M., Fleming, L.E., Miller, G., Rybolowik, M., Peter Shih, M.T., Pillai, S.P., Cooper, J.A., Quaye, E.A., 2007. Quantitative evaluation of bacteria released by bathers in a marine water. Water Research 41 (1), 3-10.

Enns, A.A., Vogel, L.J., Abdelzaher, A.M., Solo-Gabriele, H.M., Plano, L.R.W., Gidley, M.L., Phillips, M.C., Klaus, J.S., Piggot, A.M., Feng, Z., Reniers, A.J.H.M., Haus, B.K., Elmir, S.M., Zhang, Y., Jimenez, N.H., Abdel-Mottaleb, N., Schoor, M.E., Brown, A., Khan, S.Q., Dameron, A.S., Salazar, N.C., Fleming, L.E., 2012. Spatial and temporal variation in indicator microbe sampling is influential in beach management decisions. Water Research 46 (7), 2237-2246.

Gabutti, G., De Donno, A., Bagordo, F., Montagna, M.T., 2000. Comparative survival of faecal and human contaminants and use of Staphylococcus aureus as an effective indicator of human pollution. Marine Pollution Bulletin 40 (8), 697-700.

Goldstein, R.E.R., 2010. Evaluation of Antibiotic-Resistant Bacteria in Tertiary Treated Wastewater, Reclaimed Wastewater used for Spray Irrigation, and Resulting Occupational Exposures. M.P.H. University of Maryland, College Park.

Goodwin, K.D., Pobuda, M., 2009. Performance of CHROMagar ${ }^{\mathrm{TM}}$ Staph aureus and CHROMagarTM MRSA for detection of Staphylococcus aureus in beach water and sand - comparison of culture, agglutination, and molecular analyses. Water Research 43, 4802-4811.

Goodwin, K.D., Matragrano, L., Wanless, D., Sinigalliano, C., LaGier, M.J., 2009. A preliminary investigation of fecal indicator bacteria, human pathogens, and source tracking markers in beach water and sand. Environmental Research Journal 2 (4), 395-417.

Gorwitz, R.J., 2008. A review of community-associated methicillin-resistant Staphylococcus aureus skin and soft tissue infections. The Pediatric Infectious Disease Journal 27 (1), 1-7.

Halliday, E., Gast, R.J., 2011. Bacteria in beach sands: an emerging challenge in protecting coastal water quality and bather health. Environmental Science and Technology 45 (2), 370-379.

Hanes, N.B., Fossa, A.J., 1970. A qualitative analysis of the effects of bathers in recreational water quality. Advances in Water Pollution Research 5, 1-9.

Hartz, A., Cuvelier, M., Nowosielski, K., Bonilla, T.D., Green, M., Esiobu, N., McCorquodale, D.S., Rogerson, A., 2010. Survival potential of Escherichia coli and enterococci in subtropical beach sand: implications for water quality managers. Journal of Environmental Quality 37, 898-905.

Heaney, C.D., Sams, E., Wing, S., Marshall, S., Brenner, K., Dufour, A.P., Wade, T.J., 2009. Contact with beach sand among beachgoers and risk of illness. American Journal of Epidemiology 170 (2), 164-172.

Heaney, C.D., Sams, E., Dufour, A.P., Brenner, K.P., Haugland, R.A., Chern, E., Wing, S., Marshall, S., Love, D.C., Serre, M., Noble, R., Wade, T.J., 2012. Fecal indicators in sand, sand contact, and risk of enteric illness among beachgoers. Epidemiology 23 (1), 95-106.

Helsel, D.R., 2005. Nondetects and Data Analysis: Statistics for Censored Environmental Data. Wiley-Interscience, New York.

Helsel, D., 2010. Much ado about next to nothing: incorporating nondetects in science. Annals of Occupational Hygiene 54 (3), 257-262.

Hendricks, K.J., Burd, T.A., Anglen, J.O., Simpson, A.W., Christensen, G.D., Gainor, B.J., 2001. Synergy between Staphylococcus aureus and Pseudomonas aeruginosa in a rat model of complex orthopaedic wounds. Journal of Bone and Joint Surgery 83, 855-861.

Jarvis, W.R., Schlosser, J., Chinn, R.Y., Tweeten, S., Jackson, M., 2007. National prevalence of methicillin-resistant Staphylococcus aureus in inpatients at US health care facilities, 2006. American Journal of Infection Control 35 (10), 631-637.

Kluytmans, J.A.J.W., Wertheim, H.F.L., 2005. Nasal carriage of Staphylococcus aureus and prevention of nosocomial infections. Infection 33 (1), 3-8.

Kuehnert, M.J., Hill, H.A., Kupronis, B.A., Tokars, J.I., Solomon, S.L., Jernigan, D.B., 2005. Methicillin-resistantStaphylococcus aureus hospitalizations, United States. Emerging Infectious Diseases 6, 868-872.

Kuehnert, M.J., Kruszon-Moran, D., Hill, H.A., McQuillan, G., McAllister, S.K., Fosheim, G., McDougal, L.K., Chaitram, J., Jensen, B., Fridkin, S.K., Killgore, G., Tenover, F.C., 2006. Prevalence of Staphylococcus aureus nasal colonization in the United States, 2001-2002. Journal of Infectious Diseases 193 (2), 169-171.

Lee, C.M., Lin, T.Y., Lin, C.C., Kohbodi, G.A., Bhatt, A., Lee, R., Jay, J.A., 2006. Persistence of fecal indicator bacteria in Santa Monica Bay beach sediments. Water Research 40 (14), 2593-2602.

Levin-Edens, E., Bonilla, N., Meschke, J.S., Roberts, M.C., 2011. Survival of environmental and clinical strains of methicillin- 
resistant Staphylococcus aurues (MRSA) in marine and fresh waters. Water Research 45 (17), 5681-5686.

Lindenmayer, J.M., Schoenfeld, S., O'Grady, R., Carney, J.K., 1998. Methicillin-resistant Staphylococcus aureus in a high school wrestling team and the surrounding community. Archives of Internal Medicine 158 (8), 895-899.

Malik, S., Peng, H., Barton, M.D., 2006. Partial nucleotide sequencing of the mecA genes of Staphylococcus aureus isolates from cats and dogs. Journal of Clinical Microbiology 44 (2), 413-416.

Martinez, J.L., 2009. The role of natural environments in the evolution of resistance traits in pathogenic bacteria. Proceedings of the Royal Society B: Biological Sciences 276 (1667), 2521-2530.

Masmoudi, S., Denis, M., Maalej, S., 2010. Inactivation of the gene katA or sodA affects the transient entry into the viable but non-culturable response of Staphylococcus aureus in natural seawater at low temperature. Marine Pollution Bulletin 60 (12) 2209-2214.

Mason, W.J., Blevins, J.S., Beenken, K., Wibowo, N., Ojha, N., Smeltzer, M.S., 2001. Multiplex PCR protocol for the diagnosis of Staphylococcal infection. Journal of Clinical Microbiology 39 (9), 3332-3338.

Miller, M., Cook, H.A., Furuya, E.Y., Bhat, M., Lee, M.H., Vavagiakis, P., Visintainer, P., Vasquez, G., Larson, E., Lowy, F.D., 2009. Staphylococcus aureus in the community: colonization versus infection. PLoS ONE 4 (8), e6708.

Moran, G.J., Amii, R.N., Abrahamian, F.M., Talan, D.A., 2005. Methicillin-resistant Staphylococcus arueus in communityacquired skin infections. Emerging Infectious Diseases 11 (6), 928-930.

Mulvey, M.R., MacDougall, L., Cholin, B., Horsman, G., Fidyk, M., Woods, S.Saskatchewan CA-MRSA Study Group, 2005. Community-associated methicillin-resistant Staphylococcus aureus, Canada. Emerging Infectious Diseases 11 (6), 844-850.

Nuttall, T., Williams, N., Saunders, R., Dawson, S., 2008. Methicillin-resistant staphylococci in companion animals. European Journal of Companion Animal Practice 18, 280-282.

Papadakis, J.A., Mavridou, A., Richardson, S.C., Lampiri, M., Marcelou, U., 1997. Bather-related microbial and yeast populations in sand and seawater. Water Research 31 (4), 799-804.

Phillips, M.C., Solo-Gabriele, H.M., Piggot, A.M., Klaus, J.S., Zhang, Y., 2011. Relationships between sand and water quality at recreational beaches. Water Research 45 (20), 6763-6769.

Plano, L.R.W., Garza, A.C., Shibata, T., Elmier, S.M., Kish, J., Sinigalliano, C.D., Gidley, M.L., Miller, G., Withum, K., Fleming, L.E., Solo-Gabriele, H.M., 2011. Shedding of Staphylococcus aureus and methicillin-resistant Staphylococcus aureus from adult and pediatric bathers in marine waters. BMC Microbiology 11 (5). http://www.biomedcentral.com/14712180/11/5.

Ralston, E.P., Kite-Powell, H., Beet, A., 2011. An estimate of the cost of acute health effects form food- and water-born marine pathogens and toxins in the United States. Journal of Water and Health 9 (4), 680-694.

Rissing, J.P., Buxton, T.B., Horner, J.A., Shockley, R.K., Fisher, J.F., Harris, R., 1987. Synergism between Bacteroides fragilis and Staphylococcus aureus in experimental tibial osteomyelitis. Journal of Laboratory and Clinical Medicine 110 (4), 433-438.

Robinton, E.D., Mood, E.W., 1966. A quantitative and qualitative appraisal of microbial pollution of water by swimmers. A preliminary report. Journal of Hygiene (London) 64 (4), 489-499.

Rose, J.B., Haas, C.N., 1999. A risk assessment framework for the evaluation of skin infections and the potential impact of antibacterial soap washing. American Journal of Infection Control 27, S26-S33.
Rusin, P.A., Maxwell, S.L., Brooks, J.P., Gerba, C.P., Pepper, I.L., 2003. Evidence for the absence of Staphylococcus aureus in land applied biosolids. Environmental Science and Technology 37 (18), 4027-4030

Sabinro, R., Verissimo, C., Cunha, M.A., Wergikoski, B., Ferreira, F.C., Rodrigues, R., Parada, H., Falcão, L., Rosado, L., Pinheiro, C., Paixão, E., Brandão, J., 2011. Pathogenic fungi: an unacknowledged risk at coastal resorts? New insights on microbiological sand quality in Portugal. Marine Pollution Bulletin 62 (7), 1506-1511.

Schaad, U.B., 1983. Which number of infecting bacteria is of clinical relevance? Infection 11 (Suppl. 2), S87-S89.

Scott, E., Bloomfield, S.F., Barlow, C.G., 1982. An investigation of microbial contamination in the home. The Journal of Hygiene 89 (2), 279-293.

Scott, E., Duty, S., Callahan, M., 2008. A pilot study to isolate Staphylococcus aureus and methicillin-resistant $S$ aureus from environmental surfaces in the home. American Journal of Infection Control 36 (6), 458-460.

Scott, E., Duty, S., McCue, K., 2009. A critical evaluation of methicillin-resistant Staphylococcus aureus and other bacteria of medical interest on commonly touched household surfaces in relation to household demographics. American Journal of Infection Control 37 (6), 447-453.

Selvakumar, A., Borst, M., 2006. Variation of microorganism concentrations in urban stormwater runoff with land use and seasons. Journal of Water and Health 4 (1), 109-124.

Seyfried, P.L., Tobin, R.S., Brown, N.E., Ness, P.F., 1985. A prospective study of swimming-related illness. II. Morbidity and the microbiological quality of water. American Journal of Public Health 75 (9), 1071-1075.

Shah, A.H., Abdelzaher, A.M., Phillips, M., Hernandez, R., SoloGabriele, H.M., Kish, J., Scorzetti, G., Fell, J.W., Diaz, M.R., Scott, T.M., Lukasik, J., Harwood, V.J., McQuaig, S., Sinigalliano, C.D., Gidley, M.L., Wanless, D., Ager, A., Lui, J., Stewart, J.R., Plano, L.R., Fleming, L.E., 2011. Indicator microbes correlate with pathogenic bacteria, yeasts and helminthes in sand at a subtropical recreational beach site. Journal of Applied Microbiology 110 (6), 1571-1583.

Shannon, K.E., Lee, D.-Y., Trevors, J.T., Beaudette, L.A., 2007. Application of real-time quantitative PCR for the detection of selected bacterial pathogens during municipal wastewater treatment. Science of the Total Environment 382, 121-129.

Shibata, T., Solo-Gabriele, H.M., 2012. Quantitative microbial risk assessment of human illness from exposure to marine beach sand. Environmental Science and Technology 46 (5), 2799-2805.

Shuval, H., 2003. Estimating the global burden of thalassogenic diseases: human infectious diseases caused by wastewater pollution of the marine environment. Journal of Water and Health 1 (2), 53-64.

Singh, G.R.R., Marples, Kligman, A.M., 1971. Experimental Staphylococcus aureus infection in humans. The Journal of Investigative Dermatology 57, 149-161.

Sinigalliano, C.D., Fleisher, J.M., Gidley, M.L., Solo-Gabriele, H.M., Shibata, T., Plano, L.R.W., Elmir, S.M., Wanless, D., Bartkowiak, J., Boiteau, R., Withum, K., Abdelzaher, A.M., He, G., Ortega, C., Zhu, X., Wright, M.E., Kish, J., Hollenbeck, J., Scott, T., Backer, L.C., Fleming, L.E., 2010. Traditional and molecular analyses for fecal indicator bacteria in non-point source subtropical recreational marine waters. Water Research 44 (13), 3763-3772.

Smith, B.G., Dufour, A.P., 1993. Effects of the Microbiological Quality of Recreational Waters: A Simulation Study. American Society for Microbiology 93rd General Meeting: May 16-20 1993; Atlanta, GA.

Soge, O.O., Meschke, J.S., No, D.B., Roberts, M.C., 2009. Characterization of methicillin-resistant Staphylococcus aureus and methicillin-resistant coagulase-negative Staphylococcus 
spp. isolated from US West Coast public marine beaches. Journal of Antimicrobial Chemotherapy 64, 1148-1155.

Tolba, O., Loughrey, A., Goldsmith, C.E., Millar, B.C., Rooney, P.J., Moore, J.E., 2008. Survival of epidemic strains of healthcare (HAMRSA) and community-associated (CA-MRSA) methicillin resistant Staphylococcus aureus (MRSA) in river-, sea- and swimming pool water. International Journal of Hygiene and Environmental Health 211 (3-4), 398-402.

USEPA, 2004. Water quality standards for coastal and Great Lakes recreation waters; Final Rule. Federal Register 69, 67218-67243. No. 22040 CFR Part 131.

Viau, E.J., Goodwin, K.D., Yamahara, K.M., Layton, B.A., Sassoubre, L.M., Burns, S.L., Tong, H.I., Wong, S.H., Boehm, A.B., 2011. Bacterial pathogens in Hawaiian coastal streams-Associations with fecal indicators, land cover, and water quality. Water Research 45, 3279-3290.

Volkmann, H., Schwartz, T., Bischoff, P., Kirchen, S., Obst, U., 2004. Detection of clinically relevant antibiotic-resistance genes in municipal wastewater using real-time PCR (TaqMan). Journal of Microbiological Methods 56, 277-286.

Waters, A.E., Contente-Cuomo, T., Buchhagen, J., Liu, C.M., Watson, L., Pearce, K., Foster, J.T., Bowers, J., Driebe, W.E.M., Engelthaler, D.M., Keim, P.S., Price, C.J., 2011. Mulitdrugresistant Staphylococcus aureus in US meat and poultry. Clinical Infectious Diseases 52 (10), 1-4.

Weese, J.S., Dick, H., Willey, B.M., McGeer, A., Kreiswirth, B.N., Innis, B., Low, D.E., 2006. Suspected transmission of methicillin-resistant Staphylococcus aureus between domestic pets and humans in veterinary clinics and in the household. Vetinary Microbiology 115, 149-155.

Whitman, R.L., Przybyla-Kelly, K., Shively, D.A., Nevers, M.B., Byappanahalli, M.N., 2009. Hand-mouth transfer and potential for exposure to E. coli and F+ coliphage in beach sand, Chicago, Illinois. Journal of Water and Health 7 (4), 623-629.
World Health Organization, 2003. Guidelines for safe recreational water environments. In: Coastal and Fresh Waters, vol. 1. World Health Organization, Geneva.

Wright, M.E., Solo-Gabriele, H.M., Elmir, S., Fleming, L.E., 2009. Microbial load from animal feces at a recreational beach. Marine Pollution Bulletin 58 (11), 1649-1656.

Yamahara, K.M., Layton, B.A., Santoro, A.E., Boehm, A.B., 2007. Beach sands along the California coast are diffuse sources of fecal bacteria to coastal waters. Environmental Science and Technology 41 (13), 4515-4521.

Yamahara, K.M., Walters, S.P., Boehm, A.B., 2009. Growth of enterococci in unaltered, unseeded beach sands subjected to tidal wetting. Applied and Environmental Microbiology 75 (6), 1517-1524.

Yamahara, K.M., Sassoubre, L.M., Goodwin, K.D., Boehm, A.B., 2012. Occurrence and persistence of human pathogens and indicator organisms in beach sands along the California coast. Applied and Environmental Microbiology 78 (6), 1733-1745.

Yau, V., Wade, T.J., de Wilde, C.K., Colford Jr., J.M., 2009. Skinrelated symptoms following exposure to recreational water: a systematic review and meta-analysis. Water Quality Exposure and Health 1, 79-103.

Yerima, B.P.K., Ranst, E.V., 2005. Chemical properties of soils. In: Introduction to Soil Science: Soils of the Tropics. Trafford Publishing, Victoria, BC, Canada, p. 187.

Zetola, N., Francis, J.S., Nuermberger, E.L., Bishai, W.R., 2005. Community-acquired meticillin-resistant Staphylococcus aureus: an emerging threat. Lancet Infectious Disease 5, 275-286.

Zhang, L., Kinkelaar, D., Huang, Y., Li, Y., Li, X., Wang, H.H., 2011. Acquired antibiotic resistance: Are we born with it? Applied and Environmental Microbiology 77 (20), 7134-7141.

Zhu, X., Wang, J.D., Solo-Gabriele, H.M., Fleming, L.E., 2011. A water quality modeling study of non-point sources at recreational marine beaches. Water Research 45 (9), 2985-2995. 